\title{
„Polskie pogranicza w procesie przemian”. Sprawozdanie z konferencji DOI: 10.19195/2083-7763.9.20
}

W dniach 23-24 maja 2018 roku we Wrocławiu odbyła się piąta - jubileuszowa edycja Międzynarodowej Konferencji „Polskie pogranicza w procesie przemian”. Wydarzenie to zostało zorganizowane przy współpracy różnych podmiotów zajmujących się szeroko rozumianą tematyką pogranicza. Gospodarzem spotkania był Zakład Socjologii Pogranicza Instytutu Socjologii Uniwersytetu Wrocławskiego na czele z prof. dr. hab. Zbigniewem Kurczem, a także Ośrodek Badań Regionalnych i Obszarów Pogranicza Uniwersytetu Wrocławskiego. W tym roku partnerami wydarzenia byli: Centrum Interdyscyplinarnych Studiów o Polsce na Uniwersytecie Europejskim Viadrina we Frankfurcie nad Odrą, Centrum Projektów Europejskich w Warszawie, Wspólny Sekretariat Programu Współpracy INTERREG Polska-Saksonia 2014-2020 oraz Biuro Łącznikowe Wolnego Państwa Saksonia we Wrocławiu. Ponadto konferencja została objęta honorowym patronatem Marszałka Województwa Dolnośląskiego.

Swoją obecność na tym wydarzeniu zaznaczyli najznakomitsi reprezentanci różnych dyscyplin naukowych, zajmujący się tematyką pogranicza, pochodzący z najważniejszych ośrodków akademickich oraz naukowych w Polsce i Europie. Jak zauważają organizatorzy spotkania, ważne było to, że prelegenci wywodzili się głównie z placówek zlokalizowanych na pograniczach, co umożliwiło postrzeganie wielu kwestii z różnych perspektyw, a także pozwoliło wyjść poza wąskie ramy krajowego myślenia. Głównym celem tegorocznej edycji konferencji było podjęcie próby zredefiniowania pojęcia pogranicza w kontekście zmieniającej się rzeczywistości. Jak zauważył prof. dr hab. Z. Kurcz, zamiar ten wynikł nie z negacji istnienia oraz funkcjonowania pojęcia pogranicza, lecz z konieczności weryfikacji nowo powstałych pojęć odnoszących się do tego zagadnienia:

Po upływie prawie ćwierćwiecza od ukazania się pierwszych tekstów nawiązujących w tytule lub tylko pośrednio - w toku rozważań - do socjologii pogranicza nie można już kwestionować jej istnienia i tego, że funkcjonuje na równych prawach z innymi subdyscyplinami socjologii. Jednak naukowo-instytucjonalne okrzepnięcie socjologii pogranicza na zewnątrz prowadzi nie tylko do petryfikacji dotychczasowych rozstrzygnięć. Przeciwnie, w wielu przypadkach zgłaszane są nowe ujęcia w podstawowych kwestiach, choć za wcześnie jeszcze mówić o zmianie paradygmatów. Zasygnalizuję tu jedynie, że jeśli kiedyś koncentrowano uwagę na wyróżnianiu przygranicza bądź pogranicza, to z czasem pojawiły się różne typologie pograniczy w ich związkach z granicami, koncepcje transgranicza a nawet krajobrazów przygranicznych. Co jednak w największym stopniu stało się przedmiotem polemik i nowych propozycji - to próby poszukiwania pograniczy z dala od granic państwowych, wszędzie tam, gdzie występują nowe zjawiska społeczno-kulturowe lub gdzie licznie skupiają się imigranci - tak w wyniku własnych wyborów, jak i w konsekwencji decyzji podejmowanych przez władze państwowe.

Obrady konferencji naukowej „Polskie pogranicza w procesie przemian”, która na stałe wpisała się do cyklicznego kalendarza wrocławskich wydarzeń naukowo-badawczych, odbywały się w dwóch lokalizacjach, pierwszego dnia — w budynku Instytutu Socjologii Uniwersytetu Wrocławskiego przy ulicy Koszarowej. Uroczystego otwarcia konferencji dokonał jej pomysłodawca i gospodarz prof. dr hab. Z. Kurcz. Wraz z nim słowo wstępu wygłosiły reprezentantki władz samorządowych oraz uniwersyteckich. W imieniu Marszałka Województwa Dolnośląskiego zaproszonych gości powitała wicedyrektor Wy- 
działu Współpracy z Zagranicą i Projektów Międzynarodowych Celestyna Górczyńska-Owsianko, natomiast w imieniu władz Wydziału Nauk Społecznych — prodziekan ds. nauki i współpracy z zagranicą prof. dr hab. Marcelina Zuber. Każdy z prelegentów zaznaczył, jak duże znaczenie dla badań nad pograniczem ma Dolny Śląsk, a przede wszystkim Wrocław - jako jeden z największych oraz najprężniej działających w tym kierunku ośrodków akademickich w Polsce.

Pierwszy panel - W stronę teorii - moderował prof. dr hab. Andrzej Sakson (Uniwersytet im. Adama Mickiewicza w Poznaniu). Wystąpieniem otwierającym obrady był referat Jak badać zmieniające sie granice w Europie?, autorstwa dr hab. Elżbiety Opiłowskiej (Uniwersytet Wrocławski). Badaczka w swoich rozważaniach zaznaczyła, że nie ma dobrej odpowiedzi na pytanie postawione w tytule. Jednakże w jej ocenie każdy eksplorator badający pogranicza winien być świadomy pewnych jego właściwości. Swoje uwagi sprecyzowała w sześciu tezach:

I teza: Konceptualizacja i badanie granic zależy od przemian politycznych i społecznych, II teza: Kompleksowość współczesnych granic wymaga wielowymiarowego podejścia badawczego, III teza: Granice powinny być analizowane w 3 wymiarach - czasowym, przestrzennym oraz społecznym, IV teza: Odwrócenie perspektywy — badanie granic z perspektywy pograniczy i ich mieszkańców, V teza: Granice są wszędzie, VI teza: Granice są kompleksowe - potrzeba badań kompleksowych, syntezujących i porównawczych.

W kolejnym wystąpieniu - Borderscapes - ku nowej konceptualizacji przestrzeni granic - dr Irena Szlachcicowa (Uniwersytet Wrocławski) poniekąd kontynuowała myśl wyrosłą na gruncie części rozważań przedmówczyni. W swoim referacie zaprezentowała i poddała krytycznej analizie stosunkowo nową i przez niektórych obecnych na sali trafnie - bądź nie - określaną jako modną koncepcję borderscapes - krajobrazów granic autorstwa Chiary Brambilli. Z kolei prof. dr hab. Irena Machaj (Akademia im. Jakuba z Paradyża w Gorzowie Wielkopolskim) w zaprezentowanym referacie starała się odpowiedzieć na pytanie, co się dzieje z tożsamością człowieka, gdy występuje ruchliwość terytorialna. Autorka w swoich rozważaniach częstokroć podkreślała, że w nowoczesnych społeczeństwach mamy do czynienia ze słabnięciem struktur społecznych na rzecz rosnącej autonomizacji podmiotów, czego skutkiem może być rodzenie się problemu świadomości samego siebie. Według niej obecnie zauważamy zmianę istoty tożsamości społecznej $\mathrm{z}$ diachronicznej na synchroniczną.

W drugim panelu - W poszukiwaniu swoistości socjologii pogranicza - moderowanym przez prof. dr hab. I. Machaj większość uwagi poświęcono badaniom jakościowym — jako narzędziom pomagającym odkrywać czy też charakteryzować szeroko rozumiany efekt pogranicza. Prof. dr hab. Z. Kurcz w swoim referacie Imigranci na polskich pograniczach w okresie kryzysu imigracyjnego (2014-2017). Przyczynek do efektu pogranicza i portretu socjologicznego zatrzymanych zaprezentował częściowe wyniki badań terenowych, przeprowadzonych na pograniczu polsko-ukraińskim wiosną 2018 roku. Wiele uwagi poświęcił omówieniu efektu pogranicza w kontekście przestępczości. Przybliżył portret zatrzymanych na granicy, wskazał przesłanki do łamania prawa przez te osoby oraz w kontekście zdobytych podczas badań informacji pogrupował polskie pogranicza na dwa rodzaje: bramowe (wschód i zachód) oraz ramowe (północ i południe). Następnie dr Kamilla Dolińska oraz dr Natalia Niedźwiecka-Iwańczak (Uniwersytet Wrocławski) wygłosiły referat $Z$ doświadczeń badaczek 
pogranicza - problemy i postulaty. Autorki na podstawie doświadczeń zebranych podczas realizacji badań terenowych wśród mieszkańców przygranicznych miast - Gubina, Słubic i Zgorzelca - zaprezentowały refleksje związane z realizacją badań na pograniczu. Referatem zamykającym panel było wystąpienie dr Karoliny Cynk (Uniwersytet Rzeszowski). Autorka przedstawiła wyniki swoich badań, które dotyczyły występowania różnic w sposobie postrzegania problematyki ochrony środowiska przez wykładowców z pogranicznych ośrodków akademickich. Przeprowadzono wspólną dyskusję podsumowującą panel pierwszy oraz drugi. Obradujący wiele uwagi poświęcili zagadnieniom związanym z pojęciem fenomenu pogranicza, a także odwoływali się do koncepcji borderscapes.

Trzeci panel, moderowany przez prof. dr hab. Marię Zielińską (Uniwersytet Zielonogórski) - Pogranicze Wschodnie w świetle propozycji teoretycznych $i$ wyników badań własnych - skupił prelegentów zajmujących się badaniem relacji na wschodnim pograniczu Polski. Referat otwierający tę część konferencji - Wytwarzanie pogranicza - na przykładzie Polski wschodniej - wygłosił prof. dr hab. Dariusz Wojakowski (Uniwersytet Rzeszowski). Zaprezentował on częściowe wyniki badań poświęconych różnym organizacjom funkcjonującym na wschodzie kraju, które w nazwie mają słowo „pogranicze”. Na podstawie przeprowadzonych analiz wyróżnił trzy sposoby rozumienia kategorii pogranicza przez te podmioty. Pierwszy, ściśle utożsamiany z działalnością Ośrodka „Pogranicze” w Sejnach, w którym pojęcie „pogranicze” wiąże się z tradycją, duchowością oraz międzykulturowością, jest ściśle związany ze sferą wartości, ma unikatowy charakter, drugi jest obecny w narracji środowiska naukowego oraz organizacji turystycznych, przedstawia pogranicze jako przestrzeń, w której można działać, oraz trzeci - zauważany w szczególności przy granicy z Ukrainą, polegający na definiowaniu pogranicza jako obszaru współpracy partnerów po obu stronach granicy (zmierzanie w kierunku transgranicza).

Następnie prof. dr hab. Tadeusz Wiesław Popławski (Politechnika Białostocka) w referacie Transgraniczność przez pryzmat promocji gospodarczej regionu wschodniej Polski przybliżył kwestie związane ze strategią gospodarczą województwa podlaskiego. Doktor Dawid Błaszczyk (Państwowa Wyższa Szkoła Zawodowa im. Jana Pawła II, Biała Podlaska) zaprezentował referat pod tytułem Władza w sieciach relacji Europy Wschodniej - w stronę europeizacji państw i pograniczy. Natomiast doc. dr Wiesław Romanowicz (Państwowa Wyższa Szkoła Zawodowa im. Jana Pawła II, Biała Podlaska) zaprezentował wyniki autorskich badań dotyczących identyfikacji cywilizacyjnej studentów południowego Podlasia w perspektywie zaufania społecznego. Ostatnim prelegentem w panelu był mgr Bogusław Kuźniar (Uniwersytet Wrocławski) z referatem Ukraińsko-polski konflikt narodowościowy w powiecie przemyskim po 1989 roku. Dyskusja podsumowująca była wielowątkowa. Znaczną część uwagi poświęcono relacji na pograniczu polsko-ukraińskim.

Panel Pogranicze $z$ Rosja $i$ bezpieczeństwo na pograniczach, moderowany przez prof. dr hab. M. Zielińską, był czwartą, zamykającą, częścią pierwszego dnia konferencji. Profesor dr hab. A. Sakson w wygłoszonym referacie zaprezentował zachodzące przemiany społeczne na pograniczu Polski z Niemcami i Polski z obwodem kaliningradzkim Federacji Rosyjskiej przez pryzmat różnic oraz podobieństw. Następnie dr hab. Marcin Dębicki (Uniwersytet Wrocławski) w swoim wystąpieniu skupił się na problematyce związanej z zawieszeniem umowy o małym ruchu granicznym pomiędzy Polską a obwodem kaliningradzkim. Na podstawie rożnych źródeł podkreślił przyczyny oraz już zaistniałe, a także przewidywane skutki zjawiska. Ostatnim prelegentem tego dnia konferencji był dr Leszek Buller 
(Centrum Projektów Europejskich). Jego referat dotyczył poprawy bezpieczeństwa na przykładzie projektów transgranicznych. W dyskusji podsumowującej skupiono się na sytuacji na pograniczu polsko-kaliningradzkim oraz pogłębiono wątek projektów transgranicznych.

Kolejny dzień wystąpień i dyskusji miał miejsce w Biurze Łącznikowym Wolnego Państwa Saksonia we Wrocławiu. Słowo wstępu wygłosił gospodarz miejsca, Uwe Behnisch kierownik Biura łącznikowego Wolnego Państwa Saksonia we Wrocławiu. Ponadto gości powitali C. Górczyńska-Owsianko oraz dr L. Buller.

Pierwsza część drugiego dnia konferencji zaczęła się nietypowo, gdyż na wstępie przeprowadzono dyskusję panelową nawiązującą do przemian na trójstronnym pograniczu polsko-czesko-niemieckim w perspektywie integracji europejskiej. Moderatorem rozmowy była dr hab. Elżbieta Opiłowska (Uniwersytet Wrocławski). W debacie udział wzięły osoby z różnych ośrodków - zarówno polskich, jak i zagranicznych: dr Hynek Böhm (Uniwersytet Techniczny, Liberec), dr L. Buller, Kinga Hartmann-Wóycicka (Europejskie Centrum Pamięć, Edukacja, Kultura) oraz U. Behnisch. Rozmówcy w rozważaniach podzielili się między innymi głównymi osiągnięciami we współpracy transgranicznej w ramach ich działalności. Ponadto wskazali, z jakimi trudnościami i przeszkodami trzeba się obecnie liczyć na polsko-czesko-niemieckim pograniczu. Do dyskusji włączyli się również inni obecni na sali uczestnicy wydarzenia.

Następnie odbyły się obrady w ramach piątego panelu - Pogranicze polsko-niemieckie — którego moderatorem była dr hab. Julita Makaro. Doktor Sarah Kleinmann (Institut für Sächsische Geschichte und Volkskunde e.V. Drezno) zaprezentowała referat Strefy kontaktu na niemiecko-czesko-polskim pograniczu w perspektywie komparatystycznej. Autorka wiele uwagi poświęciła wpływowi projektów kulturalnych na relacje zachodzące pomiędzy mieszkańcami pograniczy. W swoich rozważaniach zauważyła, że sztuka czy muzyka to idealne dziedziny, w których społeczeństwa mogą się porozumieć bez barier językowych. Następnie wyniki swoich badań nawiązujących do konstrukcji pamięci na polsko-niemieckim pograniczu w kontekście wydarzeń powodziowych w dwadzieścia lat po powodzi tysiąclecia zaprezentował mgr Kamil Bembnista (Leibniz-Institut für Raumbezogene Sozialforschung, Berlin). Badacz starał się znaleźć odpowiedź na pytanie, jaka jest wiedza o powodzi i jakie są odczucia dwadzieścia lat później po obu stronach Odry. Referat autorstwa dr Doroty Szaban i dr hab. Beaty Trzop (Uniwersytet Zielonogórski) Inwestycje węglowe na pograniczu polsko-niemieckim $w$ dyskursie medialnym - szanse czy zagrożenia dla rozwoju regionalnego nawiązywał bezpośrednio do trudnych relacji gospodarczych na pograniczu polsko-niemieckim. Celem zrealizowanego przez prelegentki badania było przedstawienie, jak przeciwnicy inwestycji węglowych na pograniczu polsko-niemieckim kształtują obraz tych inwestycji w dyskursie medialnym - konkretnie w tożsamych serwisach internetowych po jednej i po drugiej stronie. Autorki do opracowania materiału wykorzystały technikę analizy pól semantycznych. Następnie referat pod tytułem Między otwartościa a poczuciem peryferyjności zaprezentowała mgr Justyna Kuświk (Uniwersytet Szczeciński). Dyskusja panelowa w dużej mierze skupiła się na analizie postrzegania wzajemnego Polski i Niemiec w kontekście prasy publikowanej na pograniczu.

Ostatni, szósty, panel - Polsko-niemiecka transgraniczność - poprowadził prof. dr hab. Z. Kurcz. Doktor Włodzimierz Durka (Uniwersytet Szczeciński) zaprezentował referat bezpośrednio wpisujący się w tematykę tej części konferencji, poruszył bowiem kwestię polsko-niemieckiej współpracy transgranicznej z perspektywy polskich gmin wiejskich. 
Ponadto poddał krytycznej analizie wpływ funduszy unijnych na rozwój polskiej wsi. Następnie mgr Anna Steinkamp (Uniwersytet Europejski Viadrina, Frankfurt nad Odrą) w wystąpieniu Poczatek ekspansji zagranicznej największych przedsiębiorstw produkcyjnych z polsko-niemieckiego pogranicza jako łańcuch dystansu psychicznego: internacjonalizacja $w$ ujęciu behawiorystycznym przedstawiła efekty swoich autorskich badań związanych z funkcjonowaniem przedsiębiorstw na polsko-niemieckim pograniczu. Doktor Robert Bartłomiejski (Uniwersytet Szczeciński) w swoim referacie zaprezentował wyniki analizy potencjału rozwoju miast portowych polsko-niemieckiego pogranicza w kontekście rozwoju usług turystycznych przy wykorzystaniu małych statków portowych. W świetle jego analizy polskie nadbałtyckie miejscowości stoją obecnie przed ogromną szansą rozwoju. Konferencję zakończyło wystąpienie dr Máté Tamáski (Węgierskie Archiwum Narodowe w Budapeszcie). Badacz za pomocą różnego rodzaju materiałów wizualnych — map, zdjęć oraz filmów - zaprezentował wizerunek współczesnych miast podzielonych granicą. Dyskusja podsumowująca nawiązała do współpracy gospodarczej na pograniczu polsko-niemieckim. Ponadto holistycznie podsumowano dwa dni obrad, stwierdzając, że każdy z zaprezentowanych referatów był inspiracją do podjęcia debaty.

Podsumowując, warto podkreślić, że podczas $V$ edycji konferencji dyskutowano o aktualnych problemach na polskich pograniczach, a także podjęto debatę nad nowymi podejściami teoretycznymi w studiach nad granicami i pograniczami. Wyniki konferencji zostaną opublikowane w Wydawnictwie Uniwersytetu Wrocławskiego w tomie Polskie pogranicza $w$ procesie przemian pod redakcją Z. Kurcza.

Anna Korotusz-Mirecka

ORCID: 0000-0001-6817-3256

Sprawozdanie z konferencji Jubileusz 30-lecia Wydziału Nauk Społecznych Uniwersytetu Wrocławskiego: „Nowoczesne intelektualne przywództwo dla przyszłości”. Sesja naukowa Instytutu Socjologii: „Socjologia wobec przyszłości w sferze teorii i praktyki"

DOI: 10.19195/2083-7763.9.21

W 2018 roku Wydział Nauk Społecznych Uniwersytetu Wrocławskiego obchodził jubileusz trzydziestolecia swojego istnienia. Dwudniowe święto (22-23 czerwca 2018 roku) miało na celu zintegrować i uhonorować całe środowisko akademickie biorące udział w budowaniu i tworzeniu tego wydziału, a także silnie współpracujące i działające na rzecz badań tego, co społeczne.

Pierwszy dzień rozpoczął się posiedzeniem Rady Wydziału Nauk Społecznych w murach reprezentatywnego Oratorium Marianum, w głównym gmachu Uniwersytetu Wrocławskiego, tuż obok wrocławskiego rynku. Tego dnia zaplanowano również oficjalne obchody z udziałem władz Uniwersytetu Wrocławskiego, przedstawicieli administracji rządowej i samorządowej, reprezentantów Polskiej Akademii Nauk oraz członków ogólno- 